\title{
$\frac{100}{\text { LAT RPES }}$
}

\author{
RAFAŁ ŚLIWIŃSKI*, MAGDALENA ŚLIWIŃSKA**
}

\section{THE COMPETITIVE FACTORS OF GERMAN ENTERPRISES IN POLAND}

\section{INTRODUCTION}

Many companies ask themselves what kind of competitive approach determines success on a foreign market, whether it is one or a whole set of factors. If it is a set, they may ask which factors play the key role in determining competitive and financial success on the international market.

German enterprises are very successful abroad. They are also successful in Poland. However, the relation with the Polish economy is quite unique, which definitely influences the market strategy of German companies in this region. First, as a neighbouring country, Poland's location is very attractive for investment, which means lower costs in comparison to investments on other world markets. Second, there is the difficult common history, which is still remembered in Poland and can have an influence on the employment of the skilled labour force. Third, there is still a vital difference in GDP per capita between Germany - USD46,724 in 2020, and Poland - USD15,656 in 2020. ${ }^{1}$

Despite the extensive literature on internationalization, there is a shortage of studies that clearly indicate the group of competitive factors that influence success on the foreign market. Most researchers concentrate on a narrow research area $^{2}$ or try to discover universal factors behind the international competitiveness of enterprises. ${ }^{3}$ Previous studies are very insightful and use-

* Rafał Śliwiński, Poznań University of Economics and Business, r.sliwinski@ue.poznan.pl,https://orcid.org/0000-0001-6650-9764

** Magdalena Śliwińska, Poznań University of Economics and Business, m.sliwinska@ue.poznan.pl, https://orcid.org/0000-0001-7050-9599

1 Worldbank (2020).

2 Wiklund, Shepherd (2005): 71-91; Storey (1994); Davidsson et al. (2002): 332-335; Delmar et al. (2003): 189-216; Bigsten and Gebreeyesus (2007): 813-820; Coad and Rao (2008): 633-648; Autio et al. (2007): 167-183.

3 Peters, Waterman (1984); Collins (2001); Mc Farland (2008); Simon (2009); Sliwinski (2011); Sliwinski, Sliwinska (2016). 
ful, and can constitute a broad background for our research. However, they do not address the problem of what elements of the competitive strategy determine the market success of enterprises from a high developed economy in a neighbouring, less developed country, and do not deal with such specific circumstances. We identified a gap in the literature on the description of export performance and the growth factors associated with German enterprises in Poland, which is interesting given that German enterprises are developing in Poland very successfully. With regard to this gap, the aim of this paper is to investigate the competitive strategies of German enterprises in Poland and identify the key factors shaping them.

The study was conducted in 2015 as part of the international project CLILiG, which was carried out at the University of Economics in Poznan in cooperation with the Goethe Institute from Germany and the University of Tampere from Finland. The research was qualitative, based on the method of multiple case studies. The structure of the paper encompasses a literature review, a methodology section, a report on the findings, and finally a discussion with conclusions.

\section{LITERATURE REVIEW}

The theoretical framework of the research presented in this paper is anchored in the context of competitiveness, with special attention to competitive factors. It also adopts the resource-based view (RBV), enriched by Dunning's Eclectic Theory and applied to the international market. We believe that the $\mathrm{RBV}$ of the firm explains which competitive factors in the organization contribute to the company's competitive advantage. Since RBV confirms that resources are heterogeneously distributed across organizations, and that differences in resources persist over time, ${ }^{4}$ it follows that the resources which are rare, valuable, inimitable and non-substitutable ${ }^{5}$ determine the competitive advantage which leads to a vital competitive position on the market in the longer term.

From the pool of strategic management theories, the RBV identifies the tangible and intangible resources which play a crucial role in product and process creation (value creation), which together with the firm's strategy are responsible for the competitive position on the local and foreign markets. Because the RBV facilitates (or impedes) the exploitation or enhancement of firm-specific capabilities/resources ${ }^{6}$ in the context of organizational structures, export performance ${ }^{7}$ can be vitally influenced by the way market orientation capabilities are deployed. Consequently, utilization of the organizational structures which enhance proper information management and direct

\footnotetext{
${ }^{4}$ Amit, Schoemaker (1993): 33-46; Wernerfelt (1984): 171-180.

${ }^{5}$ Barney (1991): 99-120; Wernerfelt (1984): 171-180.

${ }^{6}$ Barney et al. (2001): 643-650.

${ }^{7}$ Ray et al. (2004): 23-37.
} 
contact with the customer will result in customers who have solutions better adjusted to their needs, who are better served, and who are ultimately more satisfied. The solutions are more differentiated and very often result in excellent export performance or growth on the international market. ${ }^{8}$

Three main categories that support growth on foreign markets are human resources capabilities, strategic factors, and the company's unique characteristics. ${ }^{9}$ The first group are mostly determined by the capabilities of the organization's leader and the capabilities of the key employees. The skills, knowledge and experience influence innovations, which in turn influence the modern products or services that increase a company's domestic and international growth.

Strategic factors, like the defined strategy, business model and market definition, indicate how capabilities and resources should be deployed in order to become competitive on the market. Therefore accurate knowledge ${ }^{10}$ and the internal cohesion of the strategy's components ${ }^{11}$ determine the innovative strategies ${ }^{12}$ and market success with that set of factors. The RBV confirms that the way resources and capabilities are deployed is crucial for competitiveness and superior performance. ${ }^{13}$ Dynamic capabilities allow the reconfiguration of innovative resource/capabilities that can generate new value creating strategies. $^{14}$

A company's unique characteristics are mostly connected with technological factors, its location, or its relationships with customers or suppliers. Knowledge $\mathrm{e}^{15}$ and technological advancement lead to innovation and the products or services derived therefrom ${ }^{16}$ which result in the company being able offer the customer a new quality, which very often leads to a sales increase and company development. Therefore, companies with strong technical background have a higher-than-average growth potential, also in the international dimension. ${ }^{17}$

Dunning's Eclectic theory suggests that foreign owned firms are widely assumed to have a performance advantage over their domestic counterparts. International corporations have the means to create superior technology and the capacity to be internationally competitive. As a result, entering international markets with superior technology inevitably leads to market success, which also confirms the specific comparative advantage paradigm. ${ }^{18}$ The German market is demanding and highly competitive, therefore putting it all together: the combination of a well-developed, mature company with superior technol-

\footnotetext{
8 Morgan et al. (2009): 909-920.

9 Storey (1994): 21-31

10 Obłój (2017): 139-162; Sliwinski (2012): 31-60.

11 Rosińska-Bukowska (2017): 145-158; Ciszewska-Mlinarič et al. (2015).

12 Lewandowska et al. (2016); Eisenhardt, Sull (2001): 106-172.

13 Ray et al. (2004): 23-37.

14 Eisenhardt, Martin (2000): 1107.

15 Eisenhardt, Santos (2002): 139-164.

16 Licht, Nerlinger (1998): 1005-1022.

17 Audretsch (1995).

18 Dunning (1988): 1-31.
} 
ogy and high R\&D potential, very often equipped with superior intangible assets, ${ }^{19}$ and with a less competitive country as a neighbour - is the perfect recipe for market success, from the theoretical point of view.

In our view, competitive success and growth on the foreign market depends to a large extent on the unique combination of three categories: the human factor and its quality, strategic factors, and the individual characteristics of the firm. We believe that factors such as the market experience, the long-term strategic approach, and the proper offer addressed to the market, combined with a proper combination of price, product quality and innovativeness, are responsible for competitive success in a foreign country. However, the question remains: which factors matter the most on a foreign market?

\section{METHODOLOGY}

We have applied the qualitative multiple case study approach ${ }^{20}$ using the direct interview method and a semi-structured questionnaire. As a result, we were able to interact with the studied companies and ask in-depth questions in case of misunderstandings or doubts, or if it transpired that we required more information. The interviews were conducted with one member of the company's Board of Directors. Every interview took from 2 to 3 hours. This form of research had a vital influence on the quality of the answers and also allowed us to obtain full answers to our questions. However, it should be noted that the outcomes of the research could be biased, due to only one respondent being questioned. To compensate for potential biases, we triangulated the responses by verifying the respondent's answers with data which were derived from the companies' websites, from published articles about the researched companies, or directly from the company itself. Trained research team members created reports on the companies based on secondary data, which were compared with the results of the interviews. On this basis, we drew the conclusions which are presented in this paper.

We adopted the following criteria for selecting companies for our study. First, it had to be a German enterprise, (majority of German capital). Second, the enterprises had to operate in the Wielkopolska region and had to have a headquarters or subsidiary in this region. These criteria entailed that the selected firms represented different sectors and different sizes, because our aim was to identify factors independent of the size of the company and the sector within which it operates. We selected 53 German companies located in Wielkopolska. They were all asked to take part in the study and 13 of them agreed to cooperate with us in the project. These were: Aesculap-Chifa (Chifa-Braun corporation), Anton Roehr Logistyka, Arvato (Bertelsmann corporation), BTC, Craiss Logistik, Fresenius, Herding Polska, Hermes, MAN,

${ }^{19}$ Markusen (2002); Bellak (2004): 483-514.

${ }^{20}$ Yin (2014); Eisenhardt (1989): 532-550. 
Rehau, Roedl\&Partner, Tente, and Volkswagen. All of them agreed that their names could be revealed in this paper.

The following four questions constituted the basis of the interviews:

1 . What is the strategic aim of your firm?

2 . What is the competitive strategy of your company?

3 . What are the methods of competitive struggle against your most important competitors?

4. Which modern methods of competitive struggle does your enterprise use?

The respondents could indicate one or more factors. The responses gathered during the research were individually considered and analysed. We analysed and grouped the responses into the following issues: factors relating to competitiveness, growth on the foreign market, factors relating to the company's foreign market's success, innovativeness, and factors expediting growth. We were looking for new factors and the circumstances in which they occurred or could arise, for conditions necessary for their use, as well as patterns, correlations, similarities or differences between firms. On the basis of the answers, we identified a set of key factors affecting the competitiveness of German companies internationalizing on the Polish market.

\section{FINDINGS}

We present the findings of our research in a form which assigns the respondent's answers to every question asked. However, it is important to mention two things. First, the answers to those specific questions sometimes appeared in different parts of the interview, sometimes constituting a part of an answer to another question. The authors analysed every single interview from the point of view of every single question, gathering from the whole interview information that was relevant from the point of view of the specific question. Second, when answering the questions the respondents touched on many issues that the authors did not directly ask about, but which were useful for the analysis, as they enable the aim of this paper to be achieved.

\section{What is the strategic aim of the firm?}

This question reveals where the companies want to be in the future, from the strategic point of view. When asked about their strategic goals, the surveyed companies answered in a rather coherent way. Anton Rohr, Herding, Roedl and Hermes emphasized the financial dimension - profit. Herding pointed out that growth should be above $10 \%$ annually and the presence on the eastern markets also has strategic importance. Anton Rohr emphasized customer satisfaction as an important component of the strategic goal, and Hermes also wants to be the second or third supplier in selected niches. Roedl emphasized 'providing its services at the highest quality level'. BTC goes much 
further in terms of its strategic position, the aim of which is 'to shape the image of being a promoter of new solutions on the energy market'. In practice, this means being a psychological leader, which in the industry means being the leader of leaders. Tente, VW and Arvato indicate that their strategic goal is to be the market leader. Arvato, like BTC, adds directly that their goal is not only to be a leader on the Polish market, but to be a 'global leader of BPO industry leaders'. VW also emphasized the goal of being the 'best automotive group in Poland'. Aesculap-Chifa and MAN indicated that their strategic goal is to create value for the owner, for the group. This applies to financial results as well as production, geographic or organizational dimensions. Rehau aims at systematic and sustainable development, which should create stability and independence of the firm. On the other hand, Craiss points to a broad assortment of services offered to the customer.

\section{What is the competitive strategy of your company?}

This question tries to ascertain how the companies want to achieve their strategic aims. The results of the study indicate that quality is the essential element of the competitive strategy. This applies to all the surveyed companies, although only some of them assign it first place (Craiss, Herding, Aesculap-Chifa, Roedl, Tente). The second most important element is innovation, which is often placed as first (Rehau, VW, BTC). Rehau, by placing innovation as a priority alongside high quality, indicates that one of the ways it is done is through the replacement of conventional materials with new, more efficient ones. Arvato also emphasizes that new innovative IT solutions are an important pillar of their competitive strategy. All companies emphasized, directly or indirectly, the avoidance of price competition. Only VW emphasized their economically friendly price offer. BTC also emphasized as an element of the competitive strategy investing a large part of its profits in the training of employees who are perceived as the company's greatest value and the basis of its competitive edge. Rehau, on the other hand, pointed out that the company is also using its environmentally friendly, individual product formulas and appropriate after-sales service as elements of its competitive strategy. This last factor was also important in the competitive strategy of Tente and VW. Anton Rohr pointed out that their clients' needs and satisfaction are at the centre of their strategy. Aesculap-Chifa emphasized that credibility is also an important element of their competitive strategy. Adequate diversification of the offer (Aesculap-Chifa), matching to the needs of the niche (Hermes) or simply targeting niche markets (Herding) were important elements of the strategies of these companies. In addition, Arvato emphasizes 'adding value' to the client as an important competitive factor, as well as stability, efficiency, naturalness and security, alongside the aforementioned quality as the components of its competitive strategy.

It is noteworthy that most of the researched companies indicated that quality and innovations were elements of their competitive strategy, and this includes high quality employees, who occupy an important place. 


\section{What are the methods of competitive struggle against your most important competitors?}

Aesculap-Chifa indicates that competitive struggle takes place on an intellectual level. The company is active in many markets at the same time. In some industries, competitors focus on prices, mostly because the rival company offers an excellent service and post-service, and it is difficult to compete with it. On the other hand, in the cardiology market, for example, competitors fight on the level of technology, through developing innovations. Craiss points out that rivals compete mainly with price, image, marketing and adaptation to the client (punctuality, quality of equipment, accurate documentation preparation). Hermes points to competitive struggle in two dimensions: price - for example, Korean competitors offer 30-50\% cheaper products, doubling yearly turnover in Poland, and marketing. Strong marketing is the second important area in the company's competitive struggle. BTC emphasizes that the main criterion in public procurement is the price, which leads to a decrease in quality. With the company's ability to stand out with its quality, reliability and long-term cooperation, the company decided to resign from tenders and focus on direct contact with the client. VW indicates that competitors are struggling mainly with strong sales actions. Herding, however, focusing on niches and competing in terms of quality, indicates that the problem of competitive struggle only concerns the company to a small extent.

\section{Which modern methods of competitive struggle does your company use?}

In asking this question we tried to learn whether there are any new methods in the competitive toolbox of the studied companies. Only a few companies presented newly implemented ways of competing on the market. VW indicated that it applies strong brand marketing while continuing to develop new products, because it became clear that supporting their brand image results in better sales performance and allows the company to increase its market share on the automotive market. BTC referred to investing in the scientific projects that will contribute to the deepening of knowledge and create a positive image of the company as an employer'. These scientific projects became a new way of distinguishing the company brand for customers, creating the image of expertise and, for potential new and existing employees who want to work for the best employer, becoming an interesting employment option. Keeping in mind BTC's answer to the previous question, it should be noted that the employees, with their skills and knowledge, determine the competitive advantage of the company, hence the company's good image as an employer on the labour market is essential for BTC. Aesculap-Chifa thinks that a modern way to compete is to create the right company culture, characterized by a good approach to the employee, for example flexible working time, or $75 \%$ pay for work at 1/2 time for mothers. Roedl also mentioned the company's modern website and competition through employer branding, confirming that care for employees is an 
element of modern competition. Arvato indicated that acquiring the ISO 9001 certificate in the scope of processing and ensuring the security of databases, digital printing and the preparation and dispatch of mass correspondence constitutes for customers a confirmation of the company having the highest competence and appropriate, modern infrastructure.

It is worth stressing that the investigated firms use different approaches to competitive struggle, but tend to stress the role of good employees and new technologies, which are interesting facts from the perspective of the Polish market.

\section{DISCUSSION AND CONCLUSIONS}

This paper investigates the significance of different factors in the competitive strategies of German enterprises in Poland. The general conclusion from our research is that the most important factors for competitiveness are quality, innovations and highly skilled human capital. Those three factors definitely count as rare and valuable resources, which are difficult to imitate and substitute, which reinforces the RBV approach, according to which VRIN firms' resources help to achieve a sustainable competitive advantage by implementing fresh value-creating strategies. ${ }^{21}$

Moreover, our results are consistent with the research of Bates ${ }^{22}$ which states that the higher the human resource capabilities, the greater the likelihood that the company will enter on the path of accelerated growth also in the international perspective. This conclusion is supported by the direct answers of the studied firms, but also by broader trends in modern competition, such as the focus on employer branding, the creation of enterprise culture, establishing good working conditions for employees, and creating room for flexibility.

Our findings additionally confirm that quality and innovations are key factors of differentiation that are evident in the competitive strategies of the German enterprises ${ }^{23}$ on the Polish market. Those two factors contribute to high market growth also on the international level and high export performance. ${ }^{24}$ Furthermore, the extensive studies of German companies conducted by Herman Simon confirm our findings. ${ }^{25}$ High quality and innovativeness shape the superiority of products and services, which has been shown in multiple studies to give an edge in competitive strategy. ${ }^{26}$ Additionally, the export

21 Barney (1991): 99-120; Wernerfelt (1984): 171-180.

22 Bates (1990): 551-559.

23 Porter (1985); Lakhal (2009): 637-645.

${ }^{24}$ Sliwinski, Sliwinska (2017): 211-226; Tavassoli (2018): 294-314; Ramadani et al. (2019): 271-280; Martínez-Román et al. (2019).

25 Simon (2009): 5-35.

${ }^{26}$ e.g. Flint et al. (2011): 219-230; Slater et al. (2014): 552-566, Brem et al. (2016): 133-148. 
marketing literature singles out firms' innovativeness as a critical export marketing capability ${ }^{27}$ and identifies it as a core driver of exporters' international business success. ${ }^{28}$

Next to quality and innovation, the main factors affecting competition are prices, service, marketing and adaptation to the client. Regarding price, the researched firms try to provide attractive price/value relations and compete in terms of the other factors, however very often competition forces them to lower the general level of prices. Strong service is also acknowledged in the literature as a key factor in competition. ${ }^{29}$ Adaptation to the client means putting the customer in the centre, and this is consistent with Simon, who claimed that being close to the customer and being customer driven is a key factor that allows a company to reach the leading position in its field..$^{30}$

We also contribute to the literature on business competition by addressing the modern forms of competition in which German enterprises engage. Alongside the above-mentioned factors, they focus on strong brand marketing, engagement in the scientific projects, especially prestigious ones which create the image of a leading expert or, as Simon pointed out, creating the image of a psychological leader. In recent years, employer branding and the creation of enterprise culture supportive of employees' individual needs has become an important factor in competition. Employer branding it is not a new concept, but it increased in popularity among German firms recently with regard to the Polish market. Another one is ensuring security with databases and access to modern services such as digital printing. The last two factors are consistent with the latest trend in competition, namely competing in both the physical and digital worlds, ${ }^{31}$ which enabled companies to enter digital ecosystems and enlarge their own market by means of traditional and digital competitive advantages.

Our study confirms the thesis of RBV, showing that the quality of resources matters to a great extent in achieving market success and high export performance. It also reveals the concrete resources which contribute to successful growth on the international market. In addition, the specific comparative advantage paradigm of multinational enterprises ${ }^{32}$ is confirmed by our research. German companies in the Wielkopolska region very often have superior production technology and organizational superiority, which gives them benefits in the competitive struggle on the less economically developed Polish market. In general, it is worth noting that the use of superior production technology, as well as the organizational superiority of the German companies, influences the market changes in the Wielkopolska region, either increasing the technical level of the market offer, or in creating better working conditions for the

\footnotetext{
27 e.g. Lages et al. (2009): 47-70.

28 Calantone et al. (2006): 515-524.

${ }^{29}$ Syapsan (2019): 1336-1356.

30 Simon (2009): 78-90.

31 Kimura et al. (2019).

32 Dunning (1988): 1-31.
} 
employees. On the one hand, very often German competition poses a challenge for Polish enterprises, yet on the other, German enterprises, often due to their higher levels of competitiveness, set standards which are beneficial for both customers and employees.

Our study, building on the RBV approach and enriched by Dunning's comparative advantage paradigm of multinational enterprises, contributes to academia and industry. From a practical standpoint, the results of this study can bring vital information for researchers, managers and R\&D planners working in the field of competitiveness, internationalization and export performance. We identified the key factors of competition in our research.

Despite the above-mentioned contributions, the presented research also has some limitations. First, due to the purpose of the study, we focused on the Polish market. We would be reluctant to claim that the results of this research can be relevant for German enterprises internationalizing in other less developed countries, although as can be seen from other studies there are many similarities in the behaviour of German enterprises on other foreign markets. Second, the study relied only on the statements of one person on the management board, and on publicly available information. There was not any in-depth or long-term analysis of the functioning of the firm. Third, in order to achieve its goal, the firms selected for the study were from different sectors and of different sizes. This allowed us to identify factors independently from the sector, however, it did not allow us to compare between the studied companies or extract certain industry-specific factors. Fourth, the requirement that the companies had to be present in Wielkopolska entailed that if a company had a sales subsidiary or a production facility in the region then it was taken into account, thus German exporting firms were excluded by design. Therefore it would be advisable to do a separate study, first focusing on specific sectors, and second also considering indirect entry modes of German companies. It would also be advisable to conduct quantitative studies on the importance for foreign investors of the human capital available on local, less developed markets, and on the possibilities for using those markets as a source of innovations. The present study indicates that the potential in this area is large, and the results of such quantitative research could be important for building internationalization strategies.

Amit, R., Shoemaker, P. (1993). Strategic assets and organizational rent. Strategic Management Journal 14(1): 33-46.

Andersson, S., Wictor, I. (2003). Innovative internationalisation in new firms: born globals - the Swedish case. Journal of International Entrepreneurship 1(3): 249-255.

Audretsch, D.B. (1995). Innovation and Industry Evolution. Cambridge: MITPress.

Autio, E., Kronlund, M., Kovalainen, A. (2007). High-Growth SME support initiatives in nine countries: analysis, categorization, and recommendations. Report prepared for the Finish Ministry of Trade and Industry. Edita Publishing Ltd., Edita, Finland.

Barney, J.B. (1991). Firm resources and sustained competitive advantage. Journal of Management 17(1): 99-120.

Barney, J.B. (2001). Resource-based theories of competitive advantage: a ten year retrospective on the resource-based view. Journal of Management 27: 643-650. 
Bates, T. (1990). Entrepreneur human capital inputs and small business longevity. Review of Economics and Statistics 72: 551-559.

Bellak, C. (2004). How domestic and foreign firms differ and why does it matter? Journal of Economic Surveys 18: 483-514.

Bigsten, A., Gebreeyesus, M. (2007). The small, the young, and the productive: determinants of manufacturing firms growth in Ethiopia. Economic Development and Cultural Change 55(4): 813-840.

Brem, A., Maier, M.A., Wimschneider, C. (2016). Innovation as a source of competitive advantage: the case of Nespresso. Europea Journal of Innovation Management 19(1): 133-148.

Calantone, R.J., Cavusgil, S.T., Zhao, Y. (2002). Learning orientation, firm innovation capability and firm performance. Industrial Marketing Management 31(6): 515-24.

Ciszewska-Mlinarič, M., Obłój, K., Wąsowska, A. (2015). Strategia Korporacji. Wolters Kluewer.

Coad, A., Rao, R. (2008). Innovation and firm growth in high-tech sectors: a quantile regression approach. Research Policy 37(4): 633-648.

Collins, J. (2001). Good to Great: Why Some Companies Make the Leap... and Others Don't. Harper Publishing.

Davidsson, P., Kirchhoff, B., Hatemi-J, A., Gustavsson, H. (2002). empirical analysis of business growth factors using Swedish data. Journal of Small Business Management 40(4): 332-349.

Delmar, F., Davidsson, P., Gartner, W.B. (2003). Arriving at the high-growth firm. Journal of Business Venturing 18: 189-216.

Dunning, J.H. (1988). The eclectic paradigm of international production: a restatement and some possible extensions. Journal of International Business Studies 19(1): 1-31.

Eisenhardt, K.M. (1989). Building theories from case study research. Academy of Management Review 14(4): 532-550.

Eisenhardt, K.M., Santos, F.M. (2002). Knowledge-based view: a new theory of strategy? [in:] A. Pettigrew, H. Thomas, R. Whittington (eds.), Handbook of Strategy and Management. London: Sage Publications Ltd.: 139-164.

Eisenhardt, K., Sull, D. (2001). Strategy as simple rules. Harvard Business Review 79(1): 106-176.

Flint, D.J., Blocker, C.P., Boutin, P.J. Jr. (2011). Customer value anticipation, customer satisfaction and loyalty: an empirical examination. Industrial Marketing Management 40: 219-230.

Henderson, R., Cockburn, I. (1994). Measuring competence? Exploring firm effects in pharmaceutical research. Strategic Management Journal 15: 63-84.

Jarosiński, M., Mierzejewska, W. (2017). Success factors of international new ventures from an economy in transition. Journal of East European Management Studies 22(3): 397-420.

Kimura, R., Reeves, M., Whitaker, K. (2019). The new logic of competition, Boston Consulting Group, <https://www.bcg.com/publications/2019/new-logic-of-competition> [accessed 27 October 2020].

Lages, L.F., Silva. G., Styles, C. (2009). Relationship capabilities, quality, and innovation as determinants of export performance. Journal of International Marketing 17(4): 47-70.

Lakhal, L. (2009). Impact of quality on competitive advantage and organizational performance. The Journal of the Operational Research Society 60(5): 637-645.

Lewandowska, M., Szymura-Tyc, M., Gołębiowski, T. (2016). Innovation complementarity, innovation cooperation partners and new product exports: evidence from Poland. Journal of Business Research 69(9): 3673-3681.

Licht, G. Nerlinger, E. (1998). New technology based firms in Germany: a survey of the recent evidence. Research Policy 26: 1005-1022.

Markusen, J.R. (2002). Multinational Firms and the Theory of International Trade. CambridgeLondon: MIT Press.

Martínez-Román, J.A., Gamero, J., Delgado-González, M.L., Tamayo, J.A. (2019). Innovativeness and internationalization in SMEs: an empirical analysis in European countries. Technological Forecasting and Social Change 148 (C). doi:10.1016/j.techfore.2019.119716

McFarland, K. (2008). The Beakthrough Company. How Everyday Companies Become Extraordinary Performances. Three Rivers Press.

Morgan, N.A., Vorhies, D.W., Mason, C.H. (2009). Market orientation, marketing capabilities, and firm performance. Strategic Management Journal 30: 909-920. 
Moreno, A.M., Casillas, J.C. (2008). Entrepreneurial orientation and growth of SMEs: a causal model. Entrepreneurship Theory and Practice 32(3): 507-528.

Obłój, K. (2017). Praktyka Strategii Firmy. Poltext.

Peters, T., Waterman, R. (1984). In Search of Excellence. Lessons from America's Best Run Companies. New York: Harper \&Row.

Porter, M.E. (1985). Competitive Advantage: Creating and Sustaining Superior Performance. New York: The Free Press.

Prahalad, C.K., Hamel, G. (1990). The Core Competence of the Corporation. Harvard Business Review May/June: 79-91.

Ramadani, V., Hisrich, R.D., Abazi-Alili, H., Dana, L.-P., Panthi, L., Abazi-Bexheti, L. (2019). Product innovation and firm performance in transition economies: a multistage estimation approach. Technological Forecasting and Social Change 140: 271-280.

Ray, G., Barney, J.B., Muhanna, W.A. (2004). Capabilities, business processes, and competitive advantage: choosing the dependent variable in empirical tests of the resource-based view. Strategic Management Journal 25(1): 23-37.

Rosińska-Bukowska, M. (2017). New Approach to international competitiveness of multi-layer enterprises: a reference to macroeconomic models for the assessment of competitiveness as a benchmark. Folia Oeconomica (FOE) 6(332): 145-158.

Slater S.F., Mohr, J.J., Sengupta, S. (2014). Radical product innovation capability: literature review, synthesis, and illustrative research propositions. Journal of Product and Innovation Management 31: 552-566.

Simon, H. (2009). Hidden Champions of the Twenty-First Century: The Success Strategies of Unknown World Market Leaders. London: Springer.

Śliwiński, R. (2011). Kluczowe czynniki międzynarodowej konkurencyjności przedsiębiorstw. Poznań: Wydawnictwo Uniwersytetu Ekonomicznego w Poznaniu.

Śliwiński, R. (2012). Zasoby kształtujące konkurencyjność polskich przedsiębiorstw. Gospodarka Narodowa 4(248): 31-60.

Śliwiński, R., Śliwińska, M. (2016). Growth and internationalization of fast growing firms. Journal of East European Management Studies 21(2): 231-253.

Śliwiński R., Śliwińska, M. (2017). International development of German enterprises on the example of the Wielkopolska region. Entrepreneurial Business and Economics Review 5(2): $211-226$.

Storey, D.J. (1994). Understanding the Small Business Sector. Thomson Business Press.

Syapsan, S. (2019). The effect of service quality, innovation towards competitive advantages and sustainable economic growth: marketing mix strategy as mediating variable. Benchmarking: An International Journal 26(4): 1336-1356.

Tavassoli, S. (2018). The role of product innovation on export behavior of firms. European Journal of Innovation Management 21(2): 294-314.

Teece, D.J., Pisano, G., Shuen, A. (1997). Dynamic capabilities and strategic management. Strategic Management Journal 18: 509-533.

Venkatraman, N. (1989). The concept of fit in strategy research: toward verbal and statistical correspondence. Academy of Management Review 14: 423-444.

Weche Gelübcke, J.P. (2011). The performance of foreign affiliates in German manufacturing: evidence from a new database. <http://www.freit.org/RMET/2012/SubmittedPapers/John_P._ Weche_Geluebcke53.pdf> [accessed December 2016].

Wernerfelt, B. (1984). A resource-based view of the firm. Strategic Management Journal 5: $171-180$.

Wiklund, J., Shepherd, D.A. (2005). Entrepreneurial orientation and small business performance: a configurational approach. Journal of Business Venturing 20(1): 71-91.

Worldbank - Data on GDP/capita sourced on 24.09.2021 from <https://data.worldbank.org/indicator/NY.GDP.PCAP.CD>.

Yin, R.K. (2014). Case Study Research, Design and Methods. 5th ed. Newbury Park: Sage Publications. 


\section{THE COMPETITIVE FACTORS OF GERMAN ENTERPRISES IN POLAND}

\section{Sum mary}

The purpose of this paper is to answer the following research question: which factors relating to the international competitiveness of German enterprises are most important for the Polish market? Then, in a broader context: which competitiveness factors play a key role in helping enterprises from the highest developed countries conquer the market of a relatively less developed country? On the basis of a literature review, a research gap is identified, indicating there is a shortage of studies that clearly identify a group of factors that influence a company's success on the foreign market. The gap is filled with the empirical qualitative research and the conclusions regarding the key competitiveness factors and their effective combination. Competitive strategies and factors key for their implementation are identified, presenting the factors responsible for the growth of German enterprises on the international market (Poland) and achieving market success. The set of enterprises' competitiveness factors is established and the hierarchy those factors is presented. Although the qualitative research based on thirteen companies is not representative, the leading German enterprises provide a valuable lesson on how to successfully conquer a foreign market. The key competitiveness factors responsible for such success in the context of strategic goals, competition strategies and modern methods of competition are presented and discussed. The findings are very useful for real enterprises in internationalizing situations, where the management has to determine the competitive strategy which should lead to foreign growth and in consequence success on the international market. The study indicates what to focus on when entering the foreign market and which factors have a direct impact on the growth on the foreign market. The paper is a result of empirical research on competitiveness and provides valuable information about the set of ranked competitive factors that have a direct influence on success in a foreign market.

Keywords: competitiveness; enterprise strategy; strategic management; internationalization; competitive factors 
